\title{
Penggunaan Eufemisme dalam Kalangan Penutur Iban
}

\author{
Muhammad Zaid Daud*, Mohammad Shahrul Nizam Abd Wahid, Remmy Gedat \\ Fakulti Bahasa dan Komunikasi, Universiti Malaysia Sarawak (UNIMAS), Jalan Datuk Mohammad Musa, 94300 Kota \\ Samarahan, Sarawak, Malaysia.
}

\begin{abstract}
Abstrak
Penggunaan eufemisme digunakan dalam sesuatu ujaran adalah bagi menunjukkan suatu tabu bahasa itu kedengaran lebih sopan dan beradab jika didengari oleh pelbagai lapisan masyarakat. Namun begitu, penggunaan eufemisme dalam kalangan penutur kini terbatas penggunaannya. Oleh itu, objektif utama kajian ini akan (i) menentukan kekerapan penggunaan eufemisme dalam kalangan masyarakat Iban berdasarkan umur mereka dan (ii) untuk mengkaji faktorfaktor yang mempengaruhi penggunaan eufemisme dalam masyarakat Iban. Pendekatan kualitatif dan kuantitatif telah digunakan oleh penyelidik dengan menemu bual dua penutur bahasa Iban berumur 50 tahun ke atas berdasarkan teori Allan dan Burridge dan seterusnya, soal selidik telah diedarkan kepada 105 orang responden di Kampung Lebor, Serian, Sarawak. Hasil daripada soal selidik menunjukkan terdapat jurang umur dalam penggunaan eufemisme terutamanya bagi golongan muda iaitu sebanyak $24.8 \%$ sebagai yang terendah diikuti dengan golongan dewasa iaitu sebanyak $25.5 \%$ manakala, golongan tua mencatatkan penggunaan eufemisme yang tertinggi iaitu sebanyak 39.5\%. Di samping itu, kajian ini turut mendapati bahawa faktor penggunaan eufemisme bagi penutur Iban melibatkan perkara seperti berikut, (1) menjaga hati dan perasaan pendengar walaupun dalam keadaan marah; (2) penghormatan kepada adat, kepercayaan dan golongan yang sudah meninggal dunia; (3) perkara yang melibatkan kemudaratan seperti makhluk halus atau haiwan berbahaya serta (4) perkara yang sulit atau aib.
\end{abstract}

(C) 2018 Penerbit Universiti Malaysia Pahang

Keywords: Bahasa tabu; Eufemisme; Masyarakat Iban

The Use of Euphemisms among Iban Speakers

\begin{abstract}
Euphemism is used in utterances to ensure that taboo language sounds more polite and appropriate for people at various levels of the society. However, the use of euphemism among speakers these days is limited. Therefore, this study aims to (i) determine the frequency of euphemism use among the Iban community based on their age and (ii) to investigate the factors that influence the use of euphemism in the Iban community. Both qualitative and quantitative approaches were employed to investigate the dominant use of euphemism among Iban communities. Two speakers of Iban language aged 50 years and above were interviewed based on the theory by Allan \& Burridge (1991), and a set of questionnaire was distributed to 105 respondents at Kampung Lebor, Serian, Sarawak. The results showed that there was an age gap in the use of euphemism especially for young people at $24.8 \%$, followed by adults at $25.5 \%$ while the elderly recorded the highest use of euphemisms at 39.5\%. In addition, this study also looked into the factors that led to the use of euphemisms among Iban speakers which include to: (1) mind listeners' feeling even when one is angry; (2) ensure respect for customs, beliefs and deceased persons; (3) be aware of harmful things such as ghosts or dangerous animals and (4) be aware of embarrassing things.
\end{abstract}

Keywords: Euphemism; Iban community; Taboo language

\footnotetext{
* Corresponding author: Tel.: +60173401883

E-mail addresses: zaid_daud93@yahoo.com [Daud, M. Z.]; shahrul_abe10@yahoo.com [Abd Wahid, M.S.N.]; gremmy@unimas.my [Gedat, R.].
} 


\section{PENGENALAN}

Bahasa Iban merupakan bahasa yang dituturkan oleh suku Iban dan merupakan suku terbesar di negeri Sarawak. Bahasa Iban ini merupakan satu bahasa yang paling dominan dengan kumpulan etnolinguistik yang mencapai setengah juta penutur. Bahasa Iban dan bahasa Melayu dikatakan mempunyai hubungan kekerabatan yang erat. Kedua-dua bahasa tersebut tergolong dalam rumpun bahasa yang sama iaitu dalam rumpun bahasa Austronesia (Mohammed Azlan Mis, 2010). Merujuk Rohani (2003) pula, bahasa Iban dan bahasa Melayu berasal daripada keturunan yang sama iaitu bahasa purba Melayu-Iban seperti yang dikelompokan oleh Asmah pada tahun 1988. Hal tersebut memperlihatkan bahawa banyaknya persamaan di antara bahasa Iban dan bahasa Melayu khususnya dalam sistem fonologi. Persamaan sistem fonologi keduadua bahasa tersebut tidak terbatas kepada inventori fonem bunyi plosif [p, b, t, d, k, g] semata-mata (Asmah, 1981; Asmah \& Roseline, 2012; Rohani, 2003; Rahim, 2006; Shahidi, 2000) malah kedua-duanya turut memiliki persamaan dari aspek inventori fonem bagi vokal [i, e, ə, A, u, o]. Persamaan seperti ini membuktikan dengan jelas bahawa bahasa Iban dan bahasa Melayu adalah serumpun.

Rahim (2006) pula mengatakan bahawa kelompok bahasa Iban merupakan satu kelompok bahasa yang mempunyai darjat kesamaan yang amat tinggi dengan bahasa Melayu. Bahasa Iban ini merupakan bahasa yang menjadi lingua franca di negeri Sarawak sebagaimana bahasa Melayu menjadi lingua franca di Semenanjung Malaysia. Begitu juga dengan bahasa Inggeris yang biasa dinyatakan sebagai bahasa global dan juga lingua franca di peringkat antarabangsa (Lee Su Kim et al., 2010). Oleh sebab bahasa Iban dan bahasa Melayu berasosiasi, sudah tentunya bahasa Iban tidak terlepas daripada penggunaan eufemisme dalam kalangan penuturnya. Menurut Allan dan Burridge (1991) eufemisme merujuk kepada bentuk pilihan penggunaan bahasa alternatif terhadap ungkapan yang tidak sopan untuk digunakan bagi mengelakkan perasaan malu atau janggal. Bentuk ungkapan yang tidak sopan disebut sebagai tabu iaitu, perkara yang membawa kepada ungkapan yang tidak disenangi untuk digunakan atau bersifat konotasi negatif untuk digunakan bagi tujuan komunikasi oleh penutur pada situasi tertentu.

Dalam bidang semantik, makna konotatif atau konotasi secara umumnya merujuk kepada makna yang dikemukakan secara tersirat dalam sesebuah ujaran dan mempunyai kaitan dengan budaya, konteks penggunaan, pengalaman serta persekitaran, emosi, pendidikan dan pandangan tentang dunia (Mary Fatimah Subet \& Muhammad Zaid Daud, 2018). Hal ini demikian kerana dalam sesebuah masyarakat sememangnya mempunyai suatu peraturan ataupun etika ketika berbahasa sama ada disebabkan oleh faktor kesopanan mahupun adat dan kepercayaan (Mohammad Shahrul Nizam Abd Wahid, 2017). Manakala, Muhammad Zaid Daud, Mohammad Shahrul Nizam Abd Wahid dan Remmy Gedat (2017) pula, menjelaskan bahawa ungkapan eufemisme atau dalam bahasa Iban dikenali sebagai "Jako Silup". Oleh itu, penggunaan eufemisme dalam masyarakat Iban ini berfungsi untuk menghaluskan pengucapan, merahsiakan sesuatu perkara yang dianggap aib, menunjukkan rasa hormat, penolakan terhadap bahaya dan juga berfungsi sebagai alat pendidikan kepada masyarakat.

\section{SOROTAN LITERATUR}

Pada peringkat permulaan kajian ini, pengkaji terlebih dahulu mengaplikasikan Teori Eufemisme oleh Allan dan Burridge (1991) yang terdiri daripada 1) anggota tubuh badan, (2) seks, (3) jantina hal kelakian dan hal kewanitaan, (4) kemarahan/makian, (5) kebencian, (6) penyakit, (7) kematian, (8) ketakutan berunsurkan haiwan dan makhluk halus dan akhir sekali eufemisme (9) merujuk kepada tuhan atau agama. Rajah 1 menunjukkan konsep penggunaan dan pengkategorian eufemisme Teori Allan dan Burridge (1991) sebagai landasan kepada sesi temu bual bersama informan. 


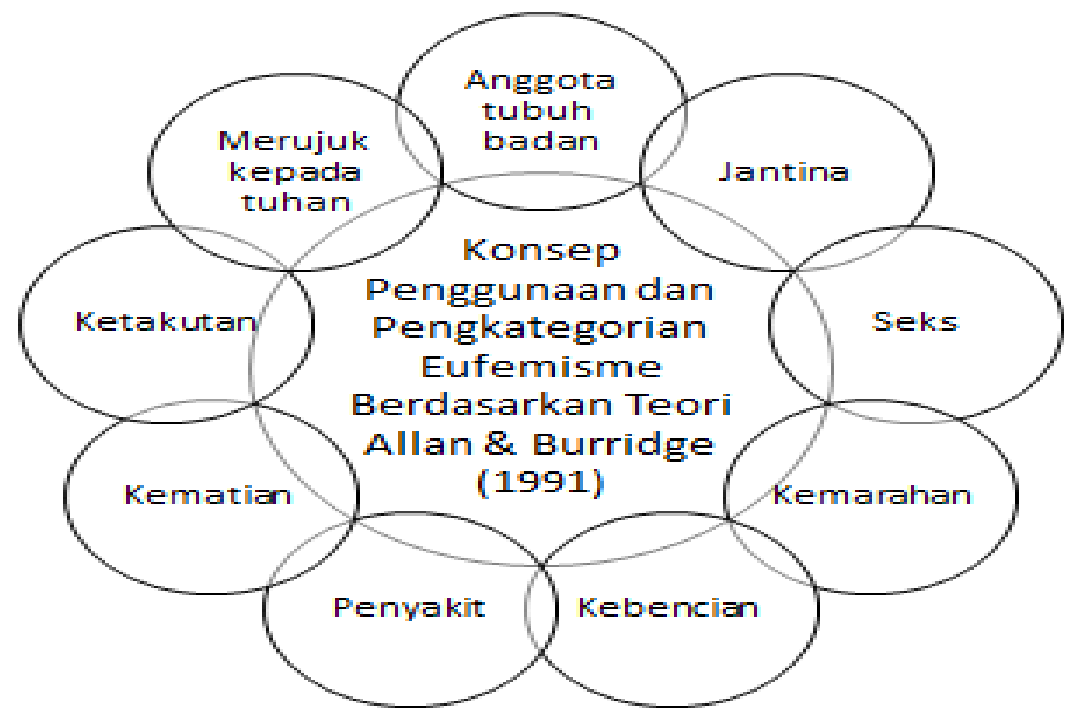

Rajah 1. Konsep penggunaan dan pengkategorian eufemisme Teori Allan \& Burridge (1991).

Seterusnya, antara sarjana-sarjana lepas yang telah menjalankan kajian berkaitan dengan eufemisme adalah seperti Muhammad Zaid Daud, Mohammad Shahrul Nizam Abd Wahid dan Remmy Gedat (2017), Hamidah Abdul Wahab, Imran Ho Abdullah, Mohammed Azlan Mis dan Khazriyati Salehuddin (2016), Petronella Apin dan Kartini Abd Wahab (2015) Harishon Radzi dan Phylisia David (2012), Razy Ronald (2012), serta Lilimiwirdi (2011). Setiap satunya mempunyai pendekatan yang tersendiri dalam menganalisis isu mengenai eufemisme dalam pelbagai perspektif yang berbeza.

Kajian Hamidah Abdul Wahab, Imran Ho Abdullah, Mohammed Azlan Mis dan Khazriyati Salehuddin (2016) telah meneliti proses-proses kognitif yang mendasari eufemisme kematian dalam masyarakat Melayu Sarawak (MMS) berdasarkan perspektif semantik kognitif yang dilakukan sarjana menggunakan kerangka teori Metafora Konsepsi dari Lakoff dan Johnson (1980). Dalam penelitian tersebut, penutur didapati menggunakan eufemisme kematian yang mana bentuk penggunaan bahasanya lebih halus dan sopan bagi menggantikan bahasa atau istilah yang dianggap kasar atau tabu dalam masyarakat, serta tidak sesuai digunakan secara langsung dalam komunikasi. Tujuan penggunaan eufemisme kematian tersebut adalah supaya menunjukkan timbang rasa serta keprihatinan agar tidak melukai perasaan pendengar.

Lilimiwirdi (2011) dalam tesis beliau bertajuk eufemisme dalam masyarakat Minangkabau di Kota Padang pula telah membuat penelitian dengan menganalisis eufemisme dengan menggabungkan dua pendekatan iaitu melalui pendekatan linguistik dan juga non-linguistik. Data yang paling banyak didapati oleh beliau dalam kajian ini ialah eufemisme dari segi kata dan frasa. Eufemisme ini adalah seperti benda, binatang, bahagian tubuh, pekerjaan, penyakit, aktiviti, peristiwa, sifat/keadaan, tempat, manusia, tumbuhtumbuhan, dan harga serta jumlah. Disebabkan data ini mempunyai makna yang tersirat, maka terjadi makna eufemisme yang tidak stabil, seperti berlaku pengaburan, penyimpangan dan pembalikan. Selain itu, makna eufemisme ini juga dilihat terdapat perluasan, penyempitan, dan perkaitan. Walau bagaimanapun, kajian ini telah memfokuskan mengenai penggunaan eufemisme dalam kalangan penutur Iban.

Terdapat juga kajian lepas yang telah meneliti aspek tersebut seperti kajian Muhammad Zaid Daud, Mohammad Shahrul Nizam Abd Wahid dan Remmy Gedat (2017), yang telah meneliti penggunaan eufemisme dalam kalangan penutur Iban di Kampung Lebor, Serian, Sarawak dengan menggunakan pendekatan teori Allan dan Burridge (1991). Berdasarkan dapatan kajian tersebut mendapati bahawa penggunaan eufemisme dalam kalangan penutur Iban memenuhi sembilan konsep penggunaan dan pengkategorian eufemisme Teori Allan dan Burridge (1991) iaitu meliputi (1) anggota tubuh badan, (2) seks, (3) jantina hal kelakian dan hal kewanitaan, (4) kemarahan/makian, (5) kebencian, (6) penyakit, (7) kematian, (8) ketakutan berunsurkan haiwan dan makhluk halus dan akhir sekali eufemisme (9) merujuk kepada tuhan 
atau agama. Dalam konteks yang sama iaitu kajian mengenai eufemisme dalam masyarakat Iban juga seperti kajian Harishon Radzi dan Phylisia David (2012). Kajian tersebut adalah untuk melihat unsur eufemisme dan perumpamaan dalam teks hikayat Iban yang membincangkan aspek kesopanan berbahasa atau penggunaan bahasa halus dalam cerita hikayat masyarakat Iban di Sarawak. Kajian ini dijalankan dengan meneliti teks cerita hikayat sebagai medium kajian, iaitu tiga buah buku cerita hikayat Iban yang memaparkan kisah kehidupan kaum Iban zaman lampau, iaitu "Bunga Nuing Ngamboh", "Lumpong Manding"dan "Satangkai".

Selain itu, kajian Razy Ronald (2012) yang bertajuk bahasa tabu dalam kalangan masyarakat Melayu daerah Serian, Sarawak bertujuan untuk merakamkan pantang larang yang pernah atau masih diamalkan oleh masyarakat Melayu pada hari ini. Kajian yang dilakukan oleh beliau juga adalah bagi mengenal pasti jenis pantang larang terhadap kaum perempuan dalam masyarakat Melayu daerah Serian, Sarawak. Selain itu, bagi membincangkan aspek nilai murni dalam pantang larang terhadap kaum perempuan dan menganalisis kesan positif dan negatif dalam pantang larang terhadap kaum perempuan.

Dapat dirumuskan bahawa, melalui kajian yang telah dijalankan oleh sarjana-sarjana yang lepas terutamanya mengenai eufemisme dalam bahasa Iban membantu pengkaji melihat kesinambungan kajiankajian yang dijalankan berdasarkan konteks sesuatu masyarakat atau budaya itu menggunakan eufemisme sebagai senjata untuk mengelakkan penggunaan bahasa yang kasar atau tabu bahasa. Selaras dengan itu, tujuan utama kajian ini adalah untuk menentukan kedominanan penggunaan eufemisme dalam kalangan masyarakat Iban mengikut peringkat umur serta mengkaji faktor-faktor yang mempengaruhi penggunaan eufemisme dalam masyarakat Iban.

\section{METODOLOGI}

Pada bahagian ini, pengkaji akan membincangkan pembangunan reka bentuk penyelidikan, lokasi kajian yang dipilih, instrumen kajian, sample kajian dan responden serta batasan kajian.

\subsection{Rekabentuk Penyelidikan}

Melalui kaedah reka bentuk penyelidikan ini pengkaji dapat memberikan gambaran mengenai kerangka, perangsangan atau strategi yang menentukan prosedur kajian seperti mana yang terdapat pada Jadual 1.

Jadual 1. Reka bentuk penyelidikan.

\begin{tabular}{cccc}
\hline $\begin{array}{c}\text { Rekabentuk } \\
\text { penyelidikan }\end{array}$ & Kaedah pengumpulan data & Informan/sampel kajian & Jenis data \\
\hline Deskriptif & Temubual mendalam & $\begin{array}{c}\text { Dua orang informan } \\
\text { berlainan jantina }\end{array}$ & Kualitatif \\
& Edaran soal selidik & 105 orang responden & Kuantitatif dan kualitatif \\
\hline
\end{tabular}

Penelitian deskriptif telah dijalankan oleh pengkaji dalam menerangkan fenomena yang berlaku seperti melihat penggunaan eufemisme dalam kalangan masyarakat Iban berdasarkan umur mereka dan untuk mengkaji faktor-faktor yang mempengaruhi penggunaan eufemisme dalam masyarakat Iban. 


\subsection{Lokasi Kajian}

Lokasi kajian yang dipilih oleh pengkaji bagi menjalankan kajian ini ialah di sebuah perkampungan etnik Iban dalam daerah Serian, Sarawak iaitu di Kampung Lebor. Jarak kampung ini dengan Universiti Malaysia Sarawak (UNIMAS) adalah kira-kira $64 \mathrm{~km}$, iaitu bersamaan 1 jam dan 5 minit perjalanan dengan menaiki kereta. Latar belakang penduduk kampung ini majoritinya adalah terdiri daripada kaum Iban Remun sahaja. Dianggarkan terdapat 200 buah rumah di kampung tersebut dan populasi penduduk lebih kurang dalam 1000 orang. Namun begitu, informan juga memberitahu bahawa terdapat juga orang luar yang menetap di kampung tersebut adalah daripada hasil perkahwinan mereka dengan penduduk tempatan. Manakala dari segi pekerjaan penduduk kampung pula, kebanyakan daripada penduduk adalah sebagai petani sawah padi, pekebun, peniaga kecil-kecilan seperti kedai runcit, pekerja kerajaan seperti tentera, pesara, guru, polis, dan juga pekerja swasta. Agama dan kepercayaan yang dianuti oleh penduduk kampung ini ialah agama Kristian. Adat istiadat yang masih diamalkan dalam kehidupan harian masyarakat adalah seperti perkahwinan cara tradisional, 'miring' (penyembahan dewa), 'bemanang' (perubatan tradisional melalui dukun/bomoh), dan juga buka rumah baru. Seni muzik dan tarian yang masih diamalkan di kampung tersebut ialah 'ngajat' iaitu tarian tradisional etnik Iban.

\subsection{Instrumen dan Prosedur Kajian}

Instrumen kajian merupakan satu alat yang digunakan oleh pengkaji ketika menjalankan sesuatu kajian bagi membantu pengkaji memperoleh data seperti mana yang dikehendaki untuk mencapai objektif kajian. Sebagai instrumen kajian ini, pengkaji telah menjalankan kajian secara dua kaedah iaitu yang pertama adalah pendekatan kualitatif iaitu melibatkan temu bual serta pemerhatian kemudiannya keduanya adalah pendekatan kuantitatif iaitu melibatkan borang soal selidik.

Oleh itu, pada peringkat temu bual, pengkaji memilih untuk menggunakan temu bual mendalam (indepth interview) yang berlandaskan 9 prinsip eufemisme oleh Allan dan Burridge (1991). Pensampelan ini menggunakan pemilihan secara NORF yang merujuk kepada non-mobile, old, remote dan female. Menurut Ong Su Teck, Nur Syahida Adilah Suri dan Rahim Aman (2016), pemilihan informan berdasarkan ciri-ciri NORF lebih sesuai di Malaysia berbanding NORM. Namun begitu, pengkaji turut menggunakan pemilihan informan secara NORM iaitu non-mobile (tinggal tetap), older (tua), rural (luar bandar) dan male (lelaki). Walau bagaimanapun, informan perempuan juga perlu diambil kira. Hal ini disebabkan oleh wujudnya keseimbangan data antara yang diambil sama ada lelaki mahupun perempuan. Menurut Asmah Haji Omar (2008) juga panduan pengutipan data daripada lelaki dan perempuan elok dipatuhi kerana mungkin dalam sesuatu masyarakat itu terdapat perbezaan antara bahasa lelaki dan perempuan dalam beberapa aspek tertentu. Pengkaji akan menemubual informan iaitu seorang lelaki dan seorang wanita berusia 50 tahun ke atas yang fasih berbahasa Iban. Temu bual dilakukan terlebih dahulu untuk mengutip leksikal-leksikal eufemisme berdasarkan domain khusus dengan berlandaskan konsep penggunaan dan pengkategorian eufemisme Teori Allan dan Burridge (1991) seperti mana yang terdapat pada Lampiran 1 Pengaplikasian teori eufemisme dalam bahasa Iban di Kampung Lebor, Serian, Sarawak.

Seterusnya, setelah leksikal eufemisme dalam bahasa Iban dikutip barulah borang soal selidik distrukturkan bagi diedarkan kepada responden. Pengkaji akan membuat edaran soal selidik untuk melihat kedominanan penggunaan istilah eufemisme mengikut peringkat umur. Seterusnya edaran soal selidik ini akan diedarkan kepada 105 orang responden yang akan diedarkan kepada 3 peringkat umur iaitu muda (1635 tahun) 35 orang, dewasa (36-50 tahun) 35 orang dan tua (51-70 tahun) 35 orang. Pensampelan mudah digunakan dalam kajian ini yang melibatkan semua peringkat umur yang fasih bertutur dalam bahasa Iban bagi melihat variasi penggunaan eufemisme dalam kesemua peringkat umur. Pada borang soal selidik tersebut juga pengkaji telah menyediakan soalan secara kualitatif untuk bertanyakan soalan "Mengapakah sebab/faktor penggunaan eufemisme/Joko' Silup (Bahasa Iban)/Bahasa Halus dalam pertuturan masyarakat Iban?" bagi mencapai objektif kajian yang kedua iaitu untuk mengkaji faktor-faktor yang mempengaruhi penggunaan eufemisme dalam masyarakat Iban. Bagi dapatan dan perbincangan kajian, pengkaji akan menganalisis data yang diperoleh dari lapangan menggunakan perisian Microsoft Excel yang melibatkan gambar rajah seperti carta bar dan pengkaji juga akan merumuskan faktor penggunaan eufemisme dalam 
kalangan masyarakat Iban berdasarkan edaran soal selidik dan temu bual secara tidak formal dengan responden.

\subsection{Kaedah Pensampelan Kajian dan Pemilihan Responden}

Kajian ini melibatkan dua pendekatan iaitu pendekatan kualitatif dengan membuat temu bual mendalam bersama dua orang informan yang terdiri daripada lelaki dan perempuan Iban berusia 50 tahun ke atas bagi mencungkil dapatan data yang melibatkan leksikal-leksikal eufemisme yang terdapat dalam ujaran penutur Iban. Seterusnya, pendekatan kuantitatif dijalankan dengan edaran soal selidik telah dijalankan secara persampelan rawak mudah di mana responden di minta untuk menjawab soal selidik yang disediakan oleh pengkaji. Oleh itu, berikut merupakan data demografi responden yang telah digunakan oleh pengkaji bagi mendapatkan data seperti mana yang terdapat dalam borang soal selidik iaitu bahagian A.

Bahagian A mengandungi data demografi responden iaitu umur, jantina, tahap pendidikan dan pekerjaan. Dapatan data bagi bahagian A ini dapat dilihat pada Jadual 2 iaitu demografi responden yang telah diedarkan di Kampung Lebor iaitu di daerah Serian, Sarawak. Seramai 105 responden telah terlibat di dalam soal selidik ini.

Jadual 2. Demografi responden.

\begin{tabular}{cccc}
\hline \multirow{2}{*}{ Item } & $\begin{array}{c}\text { Bilangan } \\
(\mathrm{n}=105)\end{array}$ & $\begin{array}{c}\text { Peratus } \\
(\%)\end{array}$ \\
\hline \multirow{3}{*}{ Umur } & Muda (16-35 Tahun) & 35 & 33.33 \\
& Dewasa (36-50 Tahun) & 35 & 33.33 \\
& Tua (51-70 Tahun) & 35 & 33.33 \\
\hline \multirow{2}{*}{ Tantinap } & Lelaki & 51 & 49 \\
& Perempuan & 54 & 51 \\
\hline Pendidikan & Tidak bersekolah & 8 & 8 \\
& Sekolah rendah/UPSR & 4 & 4 \\
& PMR/SRP & 13 & 12 \\
& SPM & 40 & 38 \\
& STPM/Diploma & 16 & 15 \\
& Ijazah Sarjana Muda & 24 & 23 \\
& Ijazah Sarjana/Master & - & - \\
\hline \multirow{3}{*}{ Pekerjaan } & PhD. & - & 42 \\
& Pelajar & 44 & 15 \\
& Pekerja Kerajaan & 16 & 20 \\
& Pekerja Swasta & 21 & 19 \\
& Bekerja sendiri & 20 & 4 \\
Pencen/Bersara & 4 & \\
\hline
\end{tabular}

Peringkat umur ini telah dibahagikan kepada 3 peringkat iaitu muda (16-35 Tahun) seramai 35 orang (34\%), dewasa (36-50 Tahun) seramai 35 orang (33\%) dan Tua (51-70 Tahun) seramai 35 orang (35\%). Manakala bagi jantina responden pula, seramai 54 orang (51\%) bagi perempuan dan 51 orang (49\%) bagi lelaki. Majoriti tahap pendidikan responden di Kampung Lebor ini adalah dari kelulusan SPM seramai 40 orang (38\%), tahap kedua iaitu Ijazah Sarjana seramai 24 orang (23\%), STPM/Diploma seramai 16 orang 
(15\%), PMR/SRP seramai 13 orang (12\%), tidak bersekolah seramai 8 orang $(8 \%)$ dan yang paling sedikit ialah pada tahap sekolah rendah/UPSR seramai 4 orang (4\%). Rata-rata responden Kampung Lebor yang menjawab soal selidik terdiri daripada golongan pelajar iaitu seramai 44 orang (42\%), seterusnya golongan pekerja swasta seramai 21 orang (20\%), bekerja sendiri seramai 20 orang (19\%), pekerja kerajaan seramai 16 orang $(15 \%)$ dan pesara/pencen seramai 4 orang $(4 \%)$.

\subsection{Batasan Kajian}

Kajian ini dibataskan kepada ungkapan eufemisme dalam bahasa Iban sahaja. Selain itu, kajian ini juga hanya dijalankan berlandaskan pendekatan Teori oleh Allan dan Burridge (1991). Malah, kajian ini hanya menumpukan kepada ungkapan eufemisme dalam bahasa Iban iaitu di Kampung Lebor dalam daerah Serian, Sarawak sahaja dan tidak pula mengkaji ungkapan eufemisme bahasa Iban di daerah/kampung yang lain. Hal ini disebabkan oleh bahasa Iban di daerah atau kampung lain juga terdapat variasi penggunaan kata eufemisme nya yang mungkin berbeza dengan bahasa Iban di Kampung Lebor. Oleh itu, dapatan kajian pengkaji hanya memfokuskan pada ungkapan eufemisme yang terdapat di kampung tersebut sahaja.

\section{ANALISIS DAN PERBINCANGAN}

Bagi melihat kedominanan penggunaan eufemisme mengikut peringkat umur, pengkaji telah mengedarkan borang soal selidik kepada 105 orang responden. Pengkaji telah membahagikan borang soal selidik kepada dua bahagian, bahagian A iaitu data demografi responden yang telah diberikan pada bahagian sample kajian dan responden manakala, pada bahagian B pula iaitu padanan kata eufemisme bagi melihat kedominanan penggunaan eufemisme bagi 3 peringkat umur dan bahagian $\mathrm{C}$ faktor penggunaan eufemisme dalam kalangan penutur Iban. Bagi soal selidik bahagian B pengkaji akan memperlihatkan kedominanan penggunaan eufemisme berdasarkan peringkat umur seperti mana yang terdapat pada rajah 2 .

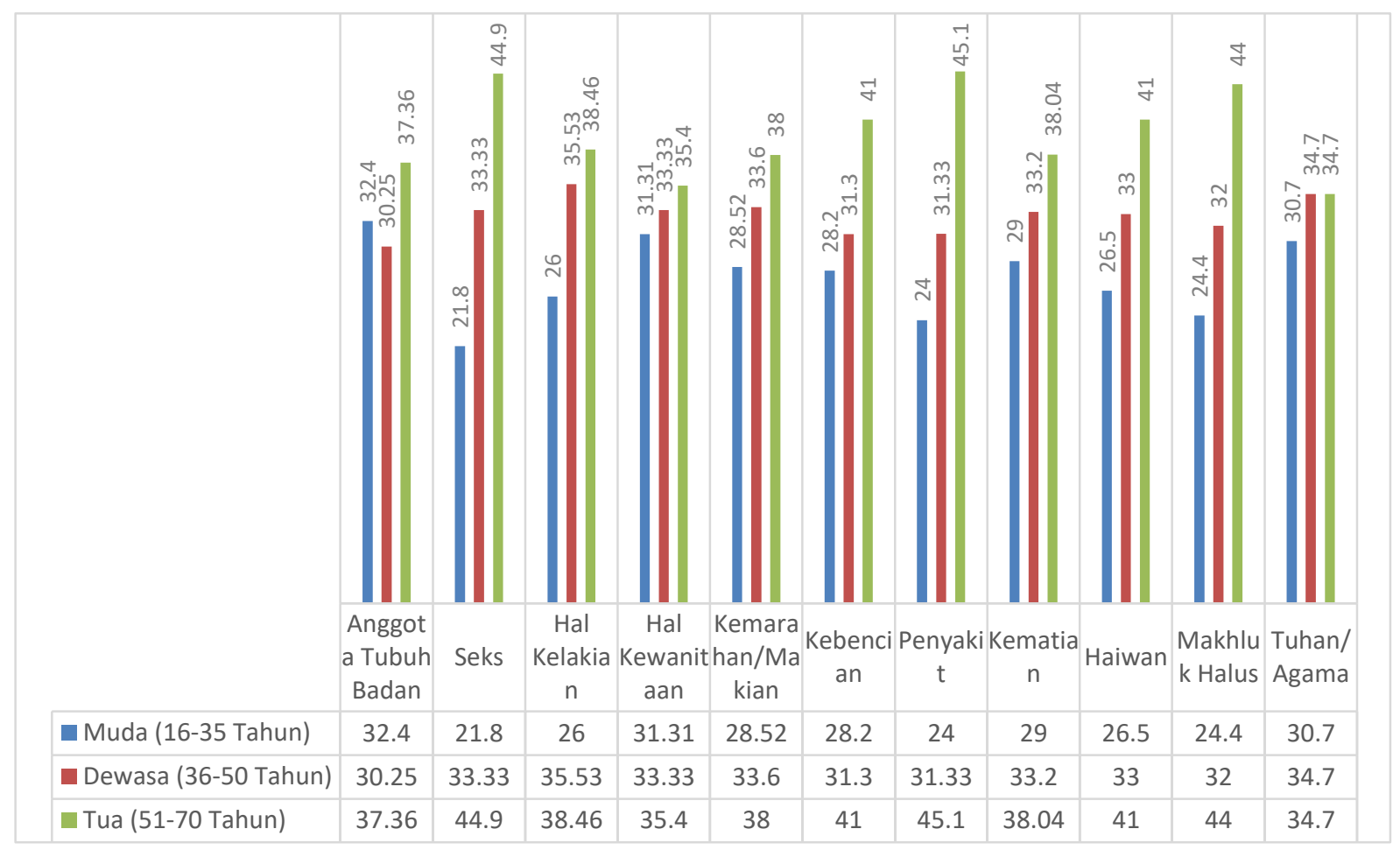

Rajah 2. Kedominanan penggunaan eufemisme berdasarkan peringkat umur 
Hasil dapatan daripada soal selidik menunjukkan bahawa terdapat kedominanan penggunaan ungkapan eufemisme daripada 3 peringkat umur ini. Kedominanan penggunaan ungkapan eufemisme ini dapat dilihat daripada eufemisme mengenai anggota tubuh badan, hal kewanitaan dan juga eufemisme yang merujuk kepada tuhan atau agama.

Kedominanan penggunaan ungkapan eufemisme mengenai anggota tubuh badan daripada soal selidik menunjukkan bahawa ketiga-ketiga peringkat umur ini menunjukkan peratusan yang agak sama iaitu golongan muda sebanyak $32.4 \%$, dewasa sebanyak $30.25 \%$ dan tua sebanyak $37.36 \%$. Kedominanan penggunaan ungkapan eufemisme mengenai anggota tubuh badan ini kerap digunakan kerana anggota tubuh badan seperti alat sulit amat sensitif untuk dibicarakan secara terbuka atau disebut secara langsung dalam perbualan antara masyarakat kerana dianggap lucah dan tidak sopan. Hal inilah yang telah mendorong ketigatiga peringkat umur untuk menggunakan ungkapan eufemisme dalam perbualan sesama masyarakat bagi menyelindungkan perkataan dalam bahasa biasa atau kasar.

Seterusnya, bagi kedominanan penggunaan ungkapan eufemisme mengenai hal kewanitaan juga turut menunjukkan peratusan yang agak sama iaitu golongan muda sebanyak $31.31 \%$, dewasa sebanyak $33.33 \%$ dan tua sebanyak $35.4 \%$. Kedominanan penggunaan ungkapan eufemisme ini menunjukkan bahawa setiap peringkat umur ini peka akan isu yang dihadapi oleh wanita seperti datang haid dan juga mengandung. Khususnya bagi penggunaan eufemisme yang merujuk kepada datang haid, kebanyakan daripada responden mengetahui akan penggantian bahasa tersebut dengan ungkapan eufemisme iaitu datai kain kerana perkara tersebut amat sensitif dan juga bagi menutup malu kepada orang yang mengalami dan juga kepada orang yang mengujarkannya.

Selain itu, kedominanan ini juga dapat dilihat melalui eufemisme yang merujuk kepada tuhan atau agama khususnya bagi rujukan kepada orang yang masih mengamalkan adat lama seperti dalam bahasa biasa iaitu kapir atau pagan yang mana pada peringkat umur muda menunjukkan peratusan sebanyak $30.7 \%$ dan dewasa serta tua masing-masing sebanyak $34.7 \%$. Penggantian bahasa biasa tersebut dengan ungkapan eufemisme agi nitih adat lama ini menunjukkan bahawa setiap peringkat umur dalam masyarakat Iban di Kampung Lebor ini amat mementingkan sifat saling menghormati antara satu sama lain dalam masyarakat.

Malah dapatan daripada soal selidik juga turut mendapati bahawa terdapat jurang perbezaan di antara penggunaan ungkapan eufemisme bagi 3 peringkat umur ini. Pengkaji mendapati bahawa terdapat penurunan penggunaan ungkapan eufemisme bagi setiap peringkat umur daripada tua, dewasa dan muda. Penggunaan ungkapan eufemisme yang dominan ini lebih ketara dapat dilihat di antara peringkat umur muda dan tua. Rata-rata golongan tua yang menjawab soal selidik mampu untuk memadankan padanan kata yang disediakan dengan betul. Namun, bagi golongan muda, pengkaji mendapati bahawa mereka tidak dapat memadankan padanan kata dengan betul dan banyak perkataan yang diminta untuk diisikan dengan jawapan yang disediakan hanya dibiarkan kosong. Di dalam soal selidik tersebut, pengkaji ada menerangkan bahawa jika responden tidak mengetahui penggunaan ungkapan eufemisme bagi perkataan bahasa halus dan kasar tersebut, responden hanya perlu membiarkan kotak jawapan tersebut kosong sahaja.

Penurunan penggunaan ungkapan eufemisme ini dapat dilihat pada eufemisme yang merujuk pada seks, hal kelakian, penyakit dan juga eufemisme yang merujuk kepada makhluk halus. Sebagai contoh, peratusan penggunaan ungkapan eufemisme yang paling sedikit dapat dilihat pada rajah iaitu eufemisme mengenai seks, peringkat umur muda menunjukkan peratusan yang paling sedikit iaitu sebanyak $21.8 \%$, diikuti oleh peringkat umur dewasa sebanyak $33.33 \%$ dan peringkat umur tua sebanyak $44.9 \%$. Perbezaan yang sangat ketara di antara golongan muda dan tua ini disebabkan oleh golongan tua sangat menjaga tutur kata mereka dalam hal kecurangan dan bersetubuh. Namun, hal ini berbeza kepada golongan muda dalam masyarakat Iban kerana mereka tidak lagi menggunakan perkataan yang berselindung seperti eufemisme dan mereka juga lebih bersikap terbuka semasa bertutur sesama mereka.

Selain itu, peratusan pengurangan penggunaan ungkapan eufemisme yang dapat dilihat ialah pada eufemisme mengenai hal kelakian iaitu golongan muda sebanyak 26\%, dewasa $35.53 \%$ dan tua $38.46 \%$. Daripada peratusan yang diperoleh, pengkaji mendapati bahawa berlaku penurunan penggunaan ungkapan eufemisme pada setiap peringkat umur. Hal ini adalah kerana, penggunaan bahasa yang merujuk hal kelakian adalah tidak seserius hal kewanitaan. Contoh yang dapat dilihat adalah kebanyakan responden yang menjawab borang soal selidik tidak mengetahui ungkapan eufemisme seperti bepayung dan angkat utai. 
Malah, eufemisme yang merujuk kepada penyakit juga turut menunjukkan peratusan pengurangan penggunaan ungkapan eufemisme iaitu golongan muda sebanyak $24 \%$, dewasa $31.33 \%$ dan tua $45.1 \%$. Jarak peratusan yang jauh antara golongan muda dan tua adalah kerana golongan muda pada masa kini tidak lagi mengetahui ungkapan eufemisme yang digunakan kerana faktor kurangnya penggunaan ungkapan eufemisme di kalangan dewasa iaitu dalam kalangan ibu bapa mereka. Hal ini telah menyebabkan mereka tidak mengetahui sama sekali ungkapan eufemisme seperti penyakit kulit iaitu samak.

Penempatan yang semakin moden dan pesat telah menyebabkan masyarakat Iban di Kampung Lebor tidak lagi mengetahui ungkapan eufemisme mengenai ketakutan terhadap makhluk halus khususnya golongan muda dan dewasa kerana masyarakat Iban sekarang tidak lagi ke hutan seperti golongan tua masyarakat Iban dahulu yang mana kebanyakan masa mereka adalah di hutan untuk mencari sumber rezeki dan juga penempatan. Hal ini telah menunjukkan penurunan penggunaan ungkapan eufemisme iaitu golongan muda sebanyak $24.4 \%$, dewasa $32 \%$ dan tua $44 \%$.

Rumusannya, dapatan daripada soal selidik menunjukkan bahawa terdapat kedominanan penggunaan ungkapan eufemisme seperti eufemisme mengenai anggota tubuh badan, hal kewanitaan dan juga eufemisme yang merujuk kepada tuhan atau agama. Malah terdapat juga jurang perbezaan di antara penggunaan ungkapan eufemisme bagi tiga peringkat umur ini yang mana penggunaan ungkapan eufemisme ini semakin jarang digunakan dalam pertuturan harian pada hari ini yang sangat berbeza dengan golongan tua pada masa dahulu yang sangat mementingkan kesopanan dalam berbahasa.

\section{FAKTOR YANG MEMPENGARUHI PENGGUNAAN EUFEMISME}

Lanjutan daripada itu, ujaran bersifat eufemisme tidak akan diujarkan tanpa ada sebab untuk diucapkan seperti mana yang terdapat dalam borang soal selidik bahagian C. Hal ini demikian kerana etnik Iban begitu kaya dengan kesopanan dalam berbahasa dan sentiasa cuba untuk menjaga hati pendengar di dalam setiap tutur kata mereka itu. Oleh itu, berdasarkan kajian ini pengkaji turut menyenaraikan faktor yang mempengaruhi penutur semasa menggunakan eufemisme dalam percakapan mereka melalui temu bual dengan responden di Kampung Lebor, Serian, Sarawak.

Terdapat beberapa faktor yang mempengaruhi penggunaan eufemisme dalam kalangan penutur etnik Iban. Antaranya untuk menjaga hati dan perasaan pendengar walaupun, dalam keadaan marah atau bergurau. Oleh itu, mereka cuba menggunakan eufemisme untuk mengawal keadaan marah mereka dengan mengujarkan perkataan-perkataan tidak bersifat kasar seperti enda mereti/enda ngamat, enda ninga dan setengah tiang yang lebih bersifat umum jika dikaitkan dengan kelakuan seseorang yang tidak mendengar kata atau tidak mengerti sesuatu perkara. Ungkapan berunsur kemarahan atau makian dalam bahasa biasa seperti paloi/tambab/tuyuk/belik, bengal/tulik dan mamau jika disebutkan akan menimbulkan rasa tidak senang kepada pendengar kerana perkataan tersebut dianggap sebagai makian dan kutukan. Dengan itu, mengawal kemarahan dalam ujaran dapat menjaga hati pendengar dan dapat mengelakkan pertelingkahan dalam kalangan mereka. Perkara ini turut ditegaskan oleh Mohamad Hashim Othman (2009) dengan mengujarkan kata-kata amarah dapat meninggalkan kesan emosi yang tinggi kepada seseorang pendengar dan sekiranya tidak menangani dengan baik, boleh menghasilkan kerosakan pada diri orang yang marah dan diri orang yang kena marah.

Selain itu, faktor penggunaan eufemisme dalam kalangan etnik Iban adalah berkaitan dengan adat dan kepercayaan sesetengah etnik Iban. Berdasarkan jumlah penduduk mengikut kumpulan etnik, agama, jantina dan negeri (Malaysia) mendapati bahawa etnik Iban mempunyai penganut beragama Kristian yang teramai di negeri Sarawak ini iaitu sebanyak 702453 orang berdasarkan pembancian tersebut namun, terdapat 45 908 orang etnik Iban yang tiada agama serta masih mengamalkan agama nenek moyang mereka (Jabatan Pendaftaran Negara, 2010). Hal ini demikian kerana terdapat sesetengah masyarakat Iban di Kampung Lebor, Serian, Sarawak yang masih mengamalkan kepercayaan nenek moyang yang mungkin bertentangan dengan agama Kristian yang merupakan agama majoriti etnik Iban. Walau bagaimanapun, etnik Iban di kampung tersebut masih menghormati agama dan kepercayaan mereka selagi tidak bercanggah dengan perundangan negara. Oleh itu, perkara ini juga dapat dikaitkan dengan ungkapan penggunaan eufemisme dalam kalangan mereka kerana mereka tidak memanggil golongan yang masih mengamalkan kepercayaan 
nenek moyang dengan panggilan Kapir/Pagan yang sudah tentu menghina kepercayaan mereka dan digantikan dengan panggilan Agi nitih adat lama yang lebih mesra untuk didengar.

Batasan ujaran atau percakapan juga dapat dikaitkan dengan faktor penggunaan eufemisme dalam kalangan etnik Iban. Perkara ini dapat dikaitkan dengan dua perkara iaitu mengenai makhluk halus dan haiwan berbahaya. Hal ini demikian kerana etnik Iban di kampung tersebut percaya bahawa jika sesuatu makhluk halus dan haiwan berbahaya diujarkan secara terus sudah tentu akan mendatangkan kecelakaan kepada penutur tersebut. Perkara ini melibatkan makna konotatif atau konotasi yang secara umumnya merujuk kepada makna yang dikemukakan secara tersirat dalam sesebuah ujaran. Menurut Norsimah Mat Awal (2014), konotasi ialah makna yang tidak berkait dengan sensa, rujukan dan denotasi tetapi mempunyai faktor tambahan seperti emosi, tahap keformalan dan adakalanya bersifat eufemisme. Oleh itu, pengkaji turun mengemukakan contoh-contoh pasangan mempunyai konotasi yang berbeza tetapi denotasi yang sama iaitu berkaitan dengan ketakutan kepada haiwan-haiwan tertentu seperti Tikuih sebagai Utai ka junggang/cit, Ular sebagai Utai ngelentang/bisi utai, Gayau/Jagu/Baya sebagai Aki. Selain itu, perkara ini turut dikaitkan dengan makhluk halus juga seperti Antu bandir, Antu Kamba dan Antu kuku digantikan dengan ungkapan eufemisme iaitu Bisi utai. Menurut Asmad (1990), kepercayaan kepada kuasa ghaib merupakan sifat semula jadi manusia pada semua zaman. Oleh itu, dengan menjaga adab percakapan dapat menjauhkan diri daripada kecelakaan.

Faktor penggunaan eufemisme dikaitkan dengan menghormati golongan yang sudah tiada. Sebagai contoh, perkataan yang kasar diungkapkan kepada si mati seperti bangkai/mayat yang sudah tentunya kasar diungkapkan dan dapat melukakan hati keluarga si mati kerana menyamakan jenazah tersebut seperti haiwan dan sepatutnya digunakan adalah tubuh yang merujuk kepada jenazah si mati. Perkara ini turut ditegaskan oleh Hamidah Abdul Wahab et al. (2016) yang menyatakan bahawa penutur haruslah menggunakan eufemisme kematian yang mana bentuk penggunaan bahasanya lebih halus dan sopan bagi menggantikan bahasa atau istilah yang dianggap kasar atau tabu dalam masyarakat serta tidak sesuai digunakan secara langsung dalam komunikasi. Tujuan penggunaan eufemisme kematian tersebut adalah supaya menunjukkan timbang rasa serta keprihatinan agar tidak melukai perasaan pendengar.

Perkara yang sulit dan aib juga dapat dikaitkan dengan faktor penggunaan eufemisme dalam kalangan etnik Iban. Hal ini demikian kerana perkara yang aib dan sulit ini dapat dikaitkan dengan perkara yang hina atau malu oleh sebab sesuatu perbuatan yang tidak sopan dan sebagainya. Menurut Akh Muhammad (2010), mereka yang menyebarkan keaiban dalam masyarakat dapat menyebabkan masyarakat menganggap kejahatan itu merupakan suatu yang biasa dan masyarakat merasa tidak aman daripada buah mulut orang lain. Sebagai contoh, berkaitan dengan seks seperti berulah/beleman (bersetubuh) yang merupakan perkara tabu untuk diceritakan kepada masyarakat umum khususnya bagi masyarakat timur. Jelas perbuatan ini merupakan punca perpecahan dan perbalahan sesama masyarakat. Bahkan, seperti juga membuka aib sendiri, membuka keaiban orang lain juga memotivasikan orang yang mendengar untuk berkongsi keaiban orang lain yang dia ketahui juga.

Faktor-faktor tersebut merupakan sebab penggunaan eufemisme dalam kalangan masyarakat Iban di Kampung Lebor, Serian, Sarawak dan perkara yang paling dititikberatkan dalam penggunaan eufemisme itu adalah untuk menjaga hati dan perasaan seseorang apabila penutur mengujarkan sesuatu perkara yang berkaitan dengan perkara-perkara tabu yang diungkapkan secara berterus terang serta kedengaran lebih sopan dan beradab jika didengari oleh pelbagai lapisan masyarakat.

\section{KESIMPULAN}

Kajian ini adalah bagi melihat tahap dominan penggunaan eufemisme dalam bahasa Iban di Kampung Lebor, Serian, Sarawak. Masyarakat Iban yang dikaji didapati masih mengamalkan penggunaan ungkapan eufemisme seperti dalam anggota tubuh badan, seks, jantina hal kelakian dan hal kewanitaan, kemarahan/makian, kebencian, penyakit, kematian, ketakutan berunsurkan haiwan, makhluk halus dan akhir sekali eufemisme merujuk kepada tuhan atau agama seperti mana yang telah digariskan oleh Allan dan Burridge (1991). Penggunaan ungkapan eufemisme dalam masyarakat Iban di Kampung Lebor ini adalah bagi menggelakkan perasaan malu dan marah, pergaduhan, musibah dan kerugian. Menurut Muhammad Zaid 
Daud (2017), bahasa yang berkias di dalam setiap pertuturan mampu menjaga hati dan perasaan pendengar walaupun dalam keadaan yang marah atau gurau senda.

Amalan penggunaan ungkapan eufemisme dalam masyarakat ini dipengaruhi kuat oleh faktor adat dan kepercayaan yang telah diwarisi sejak turun-temurun lagi. Walaupun masyarakat Iban di Kampung Lebor pada hari ini sudah melalui arus pembangunan yang serba moden. Namun begitu, penggunaan ungkapan eufemisme ini masih terus diamalkan khususnya bagi golongan tua. Penggunaan ungkapan eufemisme ini adalah bagi mewujudkan suasana yang harmoni serta saling hormat-menghormati sesama manusia dan juga terhadap alam yang sinonim dalam kehidupan masyarakat Iban. Kajian ini sebenarnya dapat melihat bagaimana penggunaan ungkapan eufemisme dalam kehidupan sehari-harian masyarakat Iban. Penggunaan ungkapan eufemisme ini banyak dipengaruhi oleh pantang larang dan kepercayaan yang diwarisi oleh masyarakat Iban sejak turun-temurun lagi. Kehebatan bahasa berkias ini bukan sahaja mampu mencerminkan kelakuan masyarakat pada zaman dahulu malahan, mampu diguna pakai sehingga kini (Muhammad Zaid Daud, 2018a, 2018b). Selain itu, kajian ini juga dapat menambahkan lagi kajian-kajian berkaitan eufemisme khususnya dalam bahasa Iban. Di samping itu, kajian ini juga dapat dijadikan panduan kepada pengkajipengkaji lain sekiranya mereka ingin membuat kajian khususnya mengenai eufemisme. Kajian eufemisme dalam bahasa Iban ini juga berfungsi sebagai wadah bagi melestarikan bahasa Iban. Hal ini kerana, bahasa Iban merupakan bahasa yang sangat unik dan penuh dengan kesantunan berbahasa.

\section{PENGHARGAAN}

Setinggi-tinggi penghargaan diberikan kepada ahli keluarga Afina Yian Anak Chundi (45422) dari Fakulti Sains dan Teknologi Sumber, Universiti Malaysia Sarawak dan ahli keluarga Cyprian Anak Marida (51563) dari Fakulti Sains Sosial, Universiti Malaysia Sarawak kerana bersama-sama menjayakan pengutipan data di Kampung Lebor, Serian, Sarawak.

\section{RUJUKAN}

Akh Muhammad. (2010, April 7). Ahlan wasahlan: Menjaga aib saudara kita [Web log post]. Retrieved from http://akh-muhammad.blogspot.my/2010/04/menjaga-aib-saudara- kita.html

Allan, K., \& Burridge, K. (1991). Euphemisme and dyphemisme language used as shield and weapon. New York: Oxford University Press.

Asmad. (1990). Kebudayaan secara umum. Kuala Lumpur: Associated Educational Distributors (M) Sdn. Bhd.

Asmah Haji Omar \& Roseline Sandai. (2012). Fonologi bahasa Iban/Fonologi jaku Iban. Tanjung Malim: Penerbit Universiti Pendidikan Sultan Idris.

Asmah Haji Omar. (2008). Asmah Haji Omar. (1981). The Iban language of Sarawak: A grammatical description. Kuala Lumpur. Dewan Bahasa dan Pustaka.

Hamidah Abdul Wahab, Imran Ho Abdullah, Mohammed Azlan Mis \& Khazriyati Salehuddin. (2016). Analisis eufemisme kematian masyarakat Melayu Sarawak dari perspektif semantik kognitif. Journal of Language Studies, 16(2), 53-71.

Harishon Radzi, \& Phylisia David. (2012). Unsur eufemisme dan perumpamaan dalam teks hikayat Iban. Jurnal Linguistik, 16, 75-87.

Jabatan Pendaftaran Negara. (2010). Jumlah penduduk mengikut kumpulan etnik, agama, jantina dan negeri, Malaysia, 2010. Retrieved from https://www.statistics.gov.my/censusatlas/ images/ReligionEN.pdf

Lakoff, G. \& Johnson, M. (1980). Metaphors We Live By. Chicago: University of Chicago Press.

Lee, S.K., Lee, K.S., Wong, F.F., \& Azizah Yaeakob. (2010). The English language and its impact on identities of multilingual Malaysian undergraduates. Journal of Language Studies, 10(1), 87-101.

Lilimiwirdi. (2011). Eufemisme dalam masyarakat Minangkabau di Kota Padang (Master's thesis, Universitas Andalas, Padang, Indonesia).

Mary Fatimah Subet, \& Muhammad Zaid Daud. (2018). Makna denotatif dan konotatif dalam slanga pelacur. MALTESAS Multi-Disciplinary Research Journal (MIRJO), 3(1), 29-43. 
Mohamad Hashim Othman. (2009). Pengurusan marah [PowerPoint slides]. Retrieved from web.usm.my/mentor/download/Mengurus\%20Amarah1.pdf

Mohammad Shahrul Nizam Abd Wahid. (2017). Eufemisme dalam bahasa Iban: Satu kajian kes di Kampung Lebor, Serian, Sarawak (Unpublished final year project). Universiti Malaysia Sarawak, Kota Samarahan, Malaysia.

Mohammed Azlan Mis. (2010). Pilihan bahasa dan lingua franca suku kaum di Sarawak. Jurnal Bahasa, $10(1)$.

Muhammad Zaid Daud, Mohammad Shahrul Nizam Abd Wahid, \& Remmy Gedat. (2017). Eufemisme dalam bahasa Iban: Satu kajian kes di Kampung Lebor, Serian, Sarawak. Borneo Research Journal, $11(1), 87-105$.

Muhammad Zaid Daud. (2017). Slanga kedai kopi: Satu analisis semantik inkuisitif (Unpublished final year project). Universiti Malaysia Sarawak, Malaysia.

Muhammad Zaid Daud. (2018a). Domain rezeki dalam peribahasa Melayu berorientasikan Aves melalui perspektif semantik inkuisitif. MALTESAS Multi-Disciplinary Research Journal (MIRJO), 3(1), 19-28.

Muhammad Zaid Daud. (2018b). Gallus gallus domesticus dan Paradoxurus hermaphroditus dalam peribahasa Melayu: Analisis semantik inkuisitif. Sains Humanika, 10(2), 41-51.

Norsimah Mat Awal. (2014). Semantik. Dlm. Mohammad Fadzeli Jaafar (pnyt.) Pengenalan linguistik: teoretis dan aplikasi. Kuala Lumpur: Dewan Bahasa dan Pustaka.

Ong, S.T., Nur Syahida Adilah Suri, \& Rahim Aman. (2016). Fonologi subdialek Pulau Pinang: Satu Kajian di Balik Pulau. Journal of Social Sciences and Humanities, 11(1).

Petronella Apin, \& Kartini Abd. Wahab. (2015). Tabu bahasa dalam masyarakat Dusun di Dearah Ranau, Sabah. Jurnal Melayu, 14(2), 224-293.

Rahim Aman. (2006). Perbandingan fonologi dan morfologi bahasa Iban, Kantuk dan Mualang. Kuala Lumpur: Dewan Bahasa dan Pustaka.

Razy Ronald. (2012). Bahasa tabu di kalangan masyarakat Melayu daerah Serian, Sarawak (Unpublished master's thesis). Universiti Putra Malaysia, Serdang, Selangor, Malaysia.

Rohani Mohd Yusof. (2003). Perkaitan bahasa Melayu dan bahasa Iban: Satu tinjauan ringkas. Jurnal Bahasa, 3(3), 457-477.

Shahidi. (2000). Analisis fonologi bahasa Iban. Jurnal Dewan Bahasa, 44(4), 434-444. 


\section{Lampiran 1: Pengaplikasian teori eufemisme dalam bahasa Iban di Kampung Lebor, Serian, Sarawak}

\begin{tabular}{|c|c|c|}
\hline \multicolumn{3}{|c|}{ Eufemisme Mengenai Anggota Tubuh Badan } \\
\hline Bahasa Biasa/Kasar & Eufemisme & Makna \\
\hline $\begin{array}{l}\text { Butuh (B) } \\
\text { Palat nuan/dik }(\mathrm{K})\end{array}$ & Loloi & Barang/benda berjuntai \\
\hline $\begin{array}{l}\text { Puki (B) } \\
\text { Palat nuan/dik (K) }\end{array}$ & Tukung & $\begin{array}{l}\text { Barang/benda dalam kain } \\
\text { perempuan }\end{array}$ \\
\hline Tusu $(\mathrm{B})$ & Buah kumbai & $\begin{array}{l}\text { Sejenis buah hutan nama saintifik - } \\
\text { Willughbeia sp.) }\end{array}$ \\
\hline \multicolumn{3}{|c|}{ Eufemisme Mengenai Seks } \\
\hline Bahasa Biasa/Kasar & Eufemisme & Makna \\
\hline Makai belalai (B) & Butang betumbang & $\begin{array}{l}\text { Curang dengan perempuan/lelaki } \\
\text { yang bukan suami/isteri sendiri }\end{array}$ \\
\hline $\begin{array}{l}\text { Bamput (B) } \\
\text { Besaki/bebong (K) }\end{array}$ & Berulah/beleman & Bersetubuh \\
\hline \multicolumn{3}{|c|}{ Eufemisme Mengenai Jantina } \\
\hline \multicolumn{3}{|c|}{ Hal Kelakian } \\
\hline Bahasa Biasa & Eufemisme & Makna \\
\hline- & Betutus & Bersunat \\
\hline Kulup (B) & Bepayung & Berpayung (Belum bersunat) \\
\hline Kenju/cego (B) & Angkat utai & Barang terangkat \\
\hline Jegak (B) & Esin-esin/lawa-lawa & $\begin{array}{l}\text { Menunjuk-nunjuk (agar nampak } \\
\text { kacak) }\end{array}$ \\
\hline \multicolumn{3}{|c|}{ Hal Kewanitaan } \\
\hline Bahasa Biasa & Eufemisme & Makna \\
\hline- & Datai kain & Datang kain \\
\hline Bunting (B) & Bertubuh bisi & Ada isi \\
\hline Jegit (B) & Lebih & Mengada-ngada \\
\hline \multicolumn{3}{|c|}{ Eufemisme Mengenai Kemarahan/Makian } \\
\hline Bahasa Biasa & Eufemisme & Makna \\
\hline Paloi/tambab/tuyuk/belik (B) & Enda mereti/enda ngamat & Tidak mengerti (Bodoh) \\
\hline Bengal/tulik (B) & Enda ninga & Tidak dengar \\
\hline Mamau (B) & Setengah tiang & Setengah tiang (Tidak siuman) \\
\hline \multicolumn{3}{|c|}{ Eufemisme Mengenai Kebencian } \\
\hline Bahasa Biasa/Kasar & Eufemisme & Makna \\
\hline Kelalu mulut (B) & Besai mulut & Besar mulut (mulut celupar) \\
\hline Berak (B) & Pedis perut/enda nyamai perut & Sakit perut/tidak sedap perut \\
\hline Maleh (B) & Siku tumpul & Siku tumpul (Pemalas) \\
\hline Indu sundal (K) & Penayang & Perempuan kotor/tidak baik \\
\hline Pondan (B) & Lentui-lentui & Lelaki lembut \\
\hline \multicolumn{3}{|c|}{ Eufemisme Mengenai Penyakit } \\
\hline Bahasa Biasa & Eufemisme & Makna \\
\hline Utai diadu orang (B) & Pansa utai & Kena ikut hantu(penyakit) \\
\hline Umbak (B) & Samak & $\begin{array}{l}\text { Dibersihkan/dijauhkan daripada } \\
\text { penyakit kulit }\end{array}$ \\
\hline Kena antu babi (B) & Kena utai babi & Dirasuk \\
\hline
\end{tabular}




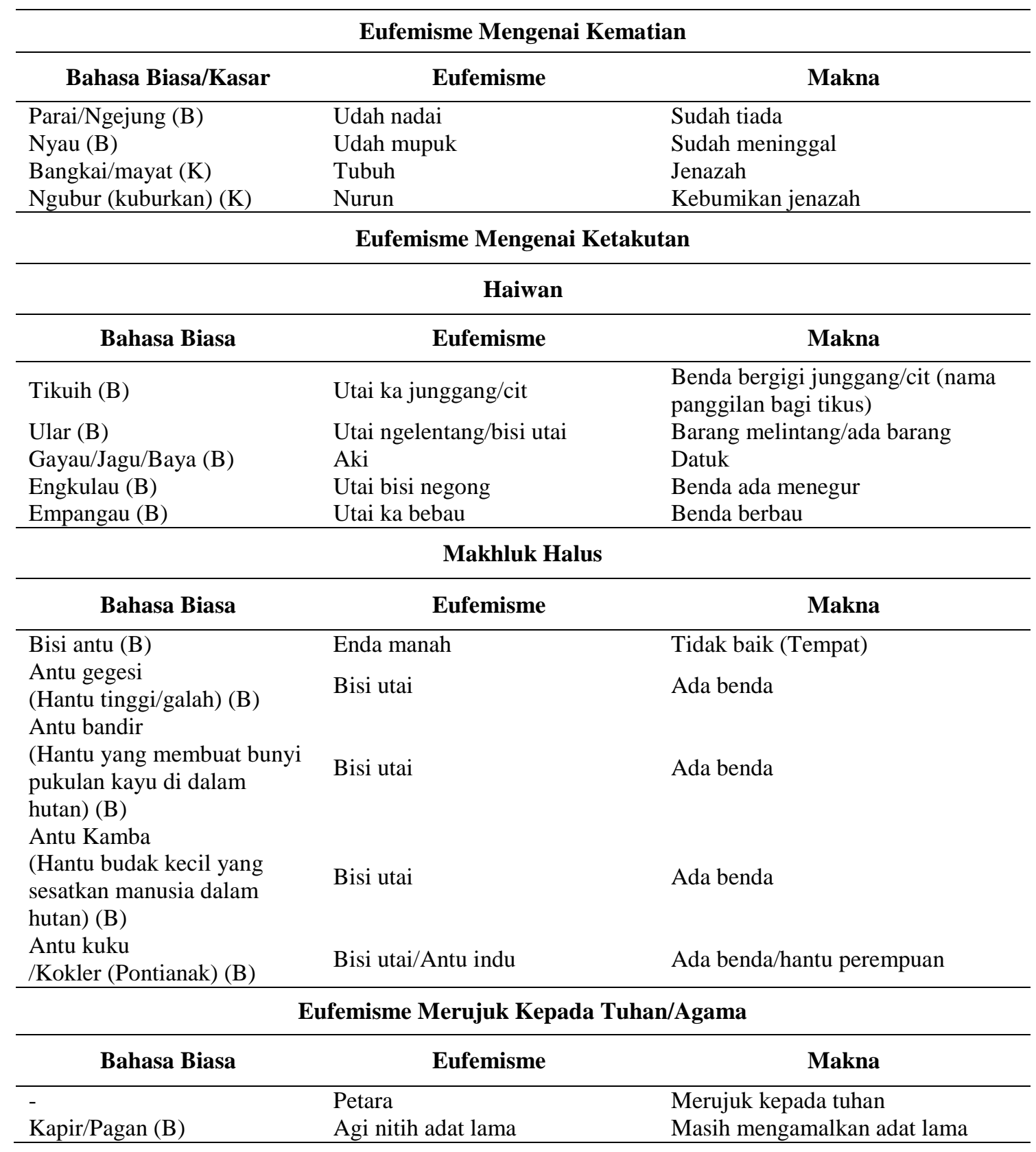

